\title{
Cross sectional study on lung function of coke oven workers: a lung function surveillance system from 1978 to 1990
}

\author{
J Wu, I A Kreis, D Griffiths, C Darling
}

See end of article for authors' affiliations

Correspondence to:

Dr I A Kreis, Graduate

School of Public Health,

University of Wollongong

NSW 2522, Australia;

irene_kreis@uow.edu.au

Accepted 14 May 2002

\begin{abstract}
Aims: To determine the association between lung function of coke oven workers and exposure to coke oven emissions.

Methods: Lung function data and detailed work histories for workers in recovery coke ovens of a steelworks were extracted from a lung function surveillance system. Multiple regressions were employed to determine significant predictors for lung function indices. The first sets of lung function tests for 613 new starters were pooled to assess the selection bias. The last sets of lung function tests for 834 subjects with one or more year of coke oven history were pooled to assess determinants of lung function.

Results: Selection bias associated with the recruitment process was not observed among the exposure groups. For subjects with a history of one or more years of coke oven work, each year of working in the most exposed "operation" position was associated with reductions in $\mathrm{FEV}_{1}$ of around $9 \mathrm{ml}$ $(p=0.006,95 \% \mathrm{Cl}: 3 \mathrm{ml}$ to $16 \mathrm{ml})$ and in FVC of around $12 \mathrm{ml}(\mathrm{p}=0.002,95 \% \mathrm{Cl}: 4 \mathrm{ml}$ to $19 \mathrm{ml})$. Negative effects of smoking on lung function were also observed.

Conclusions: Exposure to coke oven emissions was found to be associated with lower FEV, and FVC. Effects of work exposure on lung function are similar to those found in other studies.
\end{abstract}

\section{MATERIALS AND METHODS \\ Study population}

Of the 1727 subjects who ever worked in relatively highly exposed positions of coke ovens and hence were eligible to be registered in the surveillance system, 324 with no lung function measurements were excluded, along with 22 females (too few for useful analysis), and four subjects of unstated sex. There remained 1377 male subjects with at least one set of lung function measurements. The last sets (or the only sets) of lung function tests for all 1377 subjects were pooled to form the cross sectional database. This was a dynamic cohort, which allowed workers to freely join or withdraw.
More than half (738) of the subjects in the surveillance system began their coke oven work long before the surveillance system started. New starters were defined as those workers who had lung function tests within one year of commencing work at the coke ovens. A baseline analysis of the first (or only) sets of tests for 639 new starters was conducted to test for selection bias in the recruitment process. This study was approved by the ethics committee, the University of Wollongong.

\section{Occupational exposure assessment}

To assess occupational exposure level, it is desirable to obtain individual monitoring data. However, such data were not available. An alternative is to trace specific job positions at the coke ovens, and corresponding duration, for each subject. Records of the payment system in the steelworks were used to trace the detailed work history of 1163 individuals, around $84 \%$ of the population. The current job position was used to classify the 214 (around 16\%) subjects with no detailed history.

Although seven job classifications are used in the coke ovens, it was deemed appropriate to group these into four, based on perceived exposure levels, as follows:

- Operation. Subjects are mainly responsible for charging, coking, and pushing operations at the coke oven battery section.

- Maintenance. Subjects are mainly responsible for repairing mechanical facilities at the coke oven battery section.

- Electricity. Subjects are mainly responsible for fixing and repairing electrical facilities at the coke oven battery section or elsewhere.

Abbreviations: $\mathrm{BSF}$, benzene soluble fraction; $\mathrm{FEF}_{25-75 \%}$, forced mid-expiratory flow; FEV , forced expiratory volume in one second; FVC, forced vital capacity; VC, vital capacity 
- Other. This includes supervision, coal preparation, byproduct operation, and any subject whose date of lung function test is earlier than the date of starting exposure.

While by-product operation exposes workers to extracted constituents, it is appropriately grouped with "other" as being the group least exposed to coke oven emissions. The "operation" group is regarded as the most exposed. Although top and side positions in battery operation are reported to involve substantially different exposure, information from the steelworks about time spent in top or side is limited to the general statement that workers rotate regularly between the two. The exposure levels for "maintenance" and "electricity" are between the least and the most.

While individual monitoring data are not available in this study, regular monitoring of coke oven emissions commenced during the late 1970s at the same time as the medical surveillance programme. The monitoring was based on the benzene soluble fraction (BSF) of total particulate material as described in the US Federal Register of 22 October 1976. ${ }^{14}$ BSF has been an accepted universal measure of exposure to coke oven emissions throughout the world. In 1965 the American Conference of Governmental Industrial Hygienists proposed a threshold limit value (time weighted average) of $0.2 \mathrm{mg} / \mathrm{m}^{3}$ BSF. ${ }^{1}$

During the years 1983-85 the average exposure for people employed as extractor drivers, gas regulators, charger drivers, and hot car drivers (classified into "operation") was 0.19 $\mathrm{mg} / \mathrm{m}^{3}$ BSF. These occupational groupings would have had some of the higher exposures in the exposure group.

The exposure groups as used in this analysis consist of many different occupations with different exposure levels over many years as a result of ongoing operational improvements to the coke ovens and to changes in personal protection equipment use; for example, the wearing of respirators while on top of the coke ovens became mandatory in the early 1980s. The respirators used had a protection factor of 10 .

Whether analysing data on the first sets for new starters or on the last sets of tests for the whole study population, each subject was classified into the job category in which he spent the longest time up to the date of the relevant lung function test. The duration of employment in each work category was also recorded.

\section{Lung function measurements}

Initial tests were usually conducted at about the time of recruitment. For subjects having worked for five years in "operation" or having worked for 10 years in all other positions, lung function was retested at intervals of around one year.

Lung function indices measured at each test time were vital capacity (VC), forced vital capacity (FVC), and forced expiratory volume in one second $\left(\mathrm{FEV}_{1}\right)$. Forced mid-expiratory flow $\left(\mathrm{FEF}_{25-75 \%}\right)$ was included after January 1983. All of these indices were measured in a uniform manner at one centre by trained technicians using a Vitalograph spirometer.

\section{Smoking assessment}

Along with age, height, and occupational factors, smoking is recognised as a major determinant of lung function. ${ }^{13} 15$ Surveillance data only provided information, obtained at the dates of last sets of tests, on smoking status (non, ex, or current), the daily smoking level for current smokers only, and smoking years for both current and ex-smokers. For new starters, smoking status and duration for ex-smokers are compromised measures because they were only available at the dates of last sets of tests. The daily smoking level for current smokers was recorded as: 10 or fewer, $11-20,21-50$, or more than 50 cigarettes per day. The grouped values were respectively converted to: $0.25,0.75,1.75$, and 3.0 packs/day. The pack-years measure for each current smoker is the prod- uct of the number of packs consumed per day and the number of smoking years.

\section{Statistical methods}

Mean and standard deviation for continuous data and frequency and relative frequency (expressed as a percentage) for categorical data were used to summarise the data from the surveillance system.

Multiple regressions using work and smoking history as predictors were used to assess the pooled first sets of lung function tests of the 639 new starters, after adjusting for age and height. Similar multiple regressions were employed to analyse the cross sectional database, being the last sets of lung functions for all 1377 subjects. All statistical analyses were performed using the SAS software.

Lung function measurements were adjusted for age and height effects prior to regression analysis. This was done for three reasons. Firstly, some of the intended predictors, such as smoking and occupation, were correlated with age. The correlation may bias results. ${ }^{16}{ }^{17}$ Secondly, age, height, and their interaction have been included in different regression models in different functional forms in the literature. ${ }^{18-22}$ However, there is little objective evidence as to which functional forms for age, height, and their interaction should be selected as predictors. ${ }^{23}$ Thirdly, excluding age and height from the predictors can simplify the predictor selection process and refine the regressions.

Reference regressions can be used to adjust for age and height effects on lung function. ${ }^{102}$ In this study, measured lung function indices were adjusted to the values for an age of 35 years and a height of $175 \mathrm{~cm}$ using reference regressions reported by Gore et al for healthy male adult lifetime non-smokers in Australia ${ }^{24}$ :

$$
\begin{aligned}
& \text { FVC }(I)=12.675-0.0002764 \mathrm{~A}^{2}-10.736 \mathrm{H}^{2}+ \\
& 4.790 \mathrm{H}^{3}
\end{aligned}
$$

$$
\begin{aligned}
& \mathrm{FEV}_{1}(\mathrm{l})=2.081+0.5846 \mathrm{H}^{3}-0.01599 \mathrm{AH} \\
& \mathrm{FEV}_{1} / \mathrm{FVC}(\%)=92.963+0.002487 \mathrm{~A}^{2}-0.2260 \mathrm{AH} \\
& \log _{10} \mathrm{FEF}_{25-75 \%}(\mathrm{l} / \mathrm{s})=0.5707-0.00005695 \mathrm{~A}^{2}+ \\
& 0.0258 \mathrm{H}^{3}
\end{aligned}
$$

where $\mathrm{A}=$ age (years), $\mathrm{H}=$ height $(\mathrm{m})$.

If a subject was 40 years old and $170 \mathrm{~cm}$ high, his measured FVC of, say, X (e.g. $X=5.25$ ) litres would be adjusted for age and height effects to: adjusted FVC $=X-0.0002764\left(35^{2}-\right.$ $\left.40^{2}\right)-10.736\left(1.75^{2}-1.70^{2}\right)+4.790\left(1.75^{3}-1.70^{3}\right){ }^{23}$ Other indices were adjusted similarly. Because Gore et al published no reference regression for VC, this index was excluded from the analysis. Regression analyses were limited to subjects older than 18 at the dates of first sets of tests for new starters or at the dates of last sets of tests for all the population, in order to match the age range of the study population of Gore et al. This eliminated 26 subjects from the new starters, leaving 613 subjects. Cross sectional analyses for the last sets of tests were carried out on data from the whole study population (1377 subjects) less those (24) who were under 18 years old. Since the bulk of the cross sectional information comes from the longer employed subjects, these are the focus of the main analyses reported here. Specifically, a further 519 subjects with an employment duration of less than one year were excluded, with 834 subjects remaining.

\section{RESULTS}

The baseline lung function at the starting time of exposure did not differ significantly among the exposure groups. Table 1 lists the characteristics of 613 new starters who were 18 years 


\begin{tabular}{|c|c|c|c|c|c|}
\hline & \multicolumn{4}{|l|}{ Group } & \multirow[b]{2}{*}{ Total } \\
\hline & Operation & Maintenance & Electricity & Other & \\
\hline Subjects (no.) & 426 & 96 & 31 & 60 & 613 \\
\hline Age (years), mean (SD) & $27.1(8.8)$ & 29.4 (11.5) & $26.6(8.8)$ & $29.5(9.9)$ & 27.7 (9.4) \\
\hline Min-max (years) & $18.0-60.1$ & $18.2-60.1$ & $18.6-48.4$ & $18.5-58.2$ & $18.0-60.1$ \\
\hline Height $(\mathrm{cm})$, mean $(\mathrm{SD})$ & $173.7(7.2)$ & $173.3(7.9)$ & $175.7(8.3)$ & $173.6(7.8)$ & $173.7(7.4)$ \\
\hline Min-max $(\mathrm{cm})$ & $156-199$ & $153-190$ & $162-196$ & $158-193$ & $153-199$ \\
\hline Non-smokers, no. $(\%)^{*}$ & $98(23.0)$ & $23(24.0)$ & $5(16.1)$ & $16(26.6)$ & $142(23.2)$ \\
\hline Ex-smokers, no. $(\%)^{*}$ & $30(7.0)$ & $12(12.5)$ & $6(19.4)$ & $1(1.7)$ & $49(8.0)$ \\
\hline Current smokers, no. $(\%)^{*}$ & $298(70.0)$ & $61(63.5)$ & $20(64.5)$ & $43(71.7)$ & $422(68.8)$ \\
\hline$<10$ pack-years, no. $(\%) \dagger$ & $262(87.9)$ & $49(80.3)$ & $17(85.0)$ & $36(83.7)$ & $364(86.3)$ \\
\hline $10-20$ pack-years, no. $(\%) \dagger$ & $26(8.7)$ & $7(11.5)$ & $2(10.0)$ & $4(9.3)$ & $39(9.2)$ \\
\hline$\geqslant 20$ pack-years, no. $(\%) \dagger$ & $10(3.4)$ & $5(8.2)$ & $1(5.0)$ & $3(7.0)$ & $19(4.5)$ \\
\hline \multicolumn{6}{|l|}{ Lung function, mean (SD) } \\
\hline $\mathrm{FEV}_{1}(\mathrm{I}) \ddagger$ & $3.70(0.70)$ & $3.66(0.66)$ & $3.82(0.73)$ & $3.65(0.76)$ & $3.69(0.70)$ \\
\hline FVC (I) $\ddagger$ & $4.47(0.80)$ & $4.40(0.71)$ & $4.54(0.75)$ & $4.37(0.90)$ & $4.45(0.79)$ \\
\hline $\mathrm{FEV}_{1} / \mathrm{FVC}(\%) \ddagger$ & $83.82(8.14)$ & $83.16(8.02)$ & $83.85(5.53)$ & $83.63(6.97)$ & $83.00(7.89)$ \\
\hline $\mathrm{FEF}_{25-75 \%}(\mathrm{l} / \mathrm{s}) \ddagger$ & $3.88(1.30)$ & $3.64(1.29)$ & $4.07(1.57)$ & $4.23(1.14)$ & $3.87(1.29)$ \\
\hline
\end{tabular}

or older at the first sets of tests. The average starting age of the new starters was below 30, and similar in all groups. Most of the new starters (around 69\%) were current smokers. Multiple regressions were fitted for $\mathrm{FEV}_{1}, \mathrm{FVC}, \mathrm{FEV}_{1} / \mathrm{FVC}$, and $\mathrm{FEF}_{25-75 \%}$ for these new starters to assess differences among exposure groups (table 2). Coefficients for the categorical variables "operation", "maintenance", and "electricity" are not significantly different from zero $(p>0.05)$. A smoking effect was observed for the new starters on $\mathrm{FEV}_{1} / \mathrm{FVC}$ and $\mathrm{FEF}_{25-75 \%}$. The reduction for $\mathrm{FEV}_{1} / \mathrm{FVC}$ was around $1.6 \%$ $(\mathrm{p}=0.037,95 \% \mathrm{CI}: 0.1 \%$ to $3.0 \%)$ for being a current smoker, and the reduction for $\mathrm{FEF}_{25-75 \%}$ was around $37 \mathrm{ml} / \mathrm{s}(\mathrm{p}=0.005$, 95\% CI: $12 \mathrm{ml} / \mathrm{s}$ to $62 \mathrm{ml} / \mathrm{s}$ ) associated with each pack-year of smoking, indicating lower lung function for current smokers.

Table 3 profiles the surveillance data on the 834 subjects. Each exposure group had similar average age, similar average height, and similar smoking status. Current smokers comprised a strikingly high percentage of subjects (around 60\%). For subjects in the "operation" group, the average work time in "operation" was around 12 years, with a relatively short average period working in any of the other three categories and vice versa. This cross over, in term of work duration, between "operation" and the other groups was minimal.

For the multiple regressions fitted for age and height adjusted $\mathrm{FEV}_{1}, \mathrm{FVC}, \mathrm{FEV}_{1} / \mathrm{FVC}$, and $\mathrm{FEF}_{25-75 \%}$ for the 834 subjects, the coefficients for all predictors of interest are listed in table 4 . These predictors explained between around $4 \%$ and $8 \%$ of the remaining variation (after age and height adjustment) in each lung function index.

Work duration in "operation" was associated with lower lung function. For each year in "operation", FEV, was lower by about $9 \mathrm{ml}(\mathrm{p}=0.006,95 \% \mathrm{CI}: 3 \mathrm{ml}$ to $16 \mathrm{ml})$ and FVC by around $12 \mathrm{ml}(\mathrm{p}=0.002,95 \% \mathrm{CI}: 4 \mathrm{ml}$ to $19 \mathrm{ml})$. Each year of working in positions other than "operation", grouped because of similar effects and small numbers, was also associated with a lower FVC, by around $7 \mathrm{ml}(\mathrm{p}=0.034,95 \% \mathrm{CI}$ : $1 \mathrm{ml}$ to 14 $\mathrm{ml})$. The combined effects of being "operation" and work duration in "operation" on $\mathrm{FEV}_{1}$ indicated that a typical worker had significant lower FEV 1 after working in "operation" for around one year.

Effects of smoking on lung function were also observed. For each pack-year of smoking for current smokers, $\mathrm{FEV}_{1} / \mathrm{FVC}$ was lower by around $0.04 \%(p=0.040,95 \%$ CI: $0.002 \%$ to $0.08 \%)$ and $\mathrm{FEF}_{25-75 \%}$ by around $20 \mathrm{ml} / \mathrm{s}(\mathrm{p}=0.0006,95 \% \mathrm{CI}: 9 \mathrm{ml} / \mathrm{s}$ to $31 \mathrm{ml} / \mathrm{s})$. The average $\mathrm{FEV}_{1}$ and $\mathrm{FEV}_{1} / \mathrm{FVC}$ for current smokers were lower by around $116 \mathrm{ml}(\mathrm{p}=0.034,95 \% \mathrm{CI}$ : $10 \mathrm{ml}$ to 223 $\mathrm{ml})$ and around $1.9 \%(\mathrm{p}=0.020,95 \% \mathrm{CI}: 0.3 \%$ to $3.4 \%)$ respectively, compared to those for non-smokers. For exsmokers, $\mathrm{FEV}_{1}, \mathrm{FVC}, \mathrm{FEV}_{1} / \mathrm{FVC}$, and $\mathrm{FEF}_{25-75 \%}$ were lower for each year of past smoking by around $13 \mathrm{ml}(\mathrm{p}=0.0006,95 \%$ CI: $6 \mathrm{ml}$ to $20 \mathrm{ml}), 8 \mathrm{ml}$ ( $\mathrm{p}=0.042,95 \% \mathrm{CI}: 0.3 \mathrm{ml}$ to $16 \mathrm{ml}$ ), $0.3 \%(\mathrm{p}=0.0001,95 \% \mathrm{CI}: 0.1 \%$ to $0.4 \%)$, and $36 \mathrm{ml} / \mathrm{s}$ $(\mathrm{p}=0.0003,95 \% \mathrm{CI}: 17 \mathrm{ml} / \mathrm{s}$ to $55 \mathrm{ml} / \mathrm{s})$ respectively. While the average $\mathrm{FEV}_{1} / \mathrm{FVC}$ for ex-smokers was around $2.6 \%$ ( $p=0.033,95 \%$ CI: $0.2 \%$ to $5.0 \%$ ) higher than that for non-smokers, the combination of this effect with duration of ex-smoking indicates that this index was significantly lower only in ex-smokers who had smoked for more than around 10 years. This combination effect was consistent with effects found for FEV, and FVC, although in neither case was the effect of being an ex-smoker statistically significant.

When other reference regressions were used instead of those of Gore and colleagues, ${ }^{24}$ the above results were not notably changed. ${ }^{25-28}$ Furthermore, internal adjustment for age and height effects led to conclusions consistent with those obtained using reference regressions. Inclusion of the whole population of 1353 subjects, rather than only those with one or more years of work history, consistently showed weaker associations, but did not substantially change the results. The estimated decrease in FVC associated with each work year in "operation" was about $6 \mathrm{ml}(\mathrm{p}=0.027,95 \% \mathrm{CI}: 0.1 \mathrm{ml}$ to 12 $\mathrm{ml}$ ). No such significant effect was observed for any of FEV $\mathrm{FEV}_{1} / \mathrm{FVC}$, and $\mathrm{FEF}_{25-75 \%}$. The work location of "operation" had a significant effect on $\mathrm{FEV}_{1}$ (lower by around $115 \mathrm{ml}$ $(\mathrm{p}=0.030,95 \% \mathrm{CI}: 12 \mathrm{ml}$ to $218 \mathrm{ml})$ ) and on FVC (lower by around $141 \mathrm{ml}(\mathrm{p}=0.014,95 \% \mathrm{CI}: 29 \mathrm{ml}$ to $254 \mathrm{ml}))$, compared with the work location of "other".

\section{DISCUSSION}

Although there were 324 male subjects without any lung function measurements in the surveillance system, nonresponse bias can be considered small because $81 \%$ of male subjects who ever worked in relatively highly exposed positions at the coke ovens are included in the study population. 


\begin{tabular}{|c|c|c|c|c|c|c|c|c|}
\hline & \multicolumn{2}{|l|}{$\mathrm{FEV}_{1}(\mathrm{l})$} & \multicolumn{2}{|l|}{ FVC (I) } & \multicolumn{2}{|l|}{$\mathrm{FEV}_{1} / \mathrm{FVC}(\%)$} & \multicolumn{2}{|l|}{$\mathrm{FEF}_{25-75 \%}(\mathrm{I} / \mathrm{s})$} \\
\hline & Coefficient & $\mathrm{p}$ value & Coefficient & $\mathrm{p}$ value & Coefficient & p value & Coefficient & $\mathrm{p}$ value \\
\hline Intercept & $\begin{array}{l}3.58 \\
(3.43 \text { to } 3.73)^{*}\end{array}$ & 0.0001 & $\begin{array}{l}4.27 \\
(4.10 \text { to } 4.43)\end{array}$ & 0.0001 & $\begin{array}{l}83.5 \\
(81.4 \text { to } 85.7)\end{array}$ & 0.0001 & $\begin{array}{l}4.38 \\
(3.76 \text { to } 5.00)\end{array}$ & 0.0001 \\
\hline Ex-smokers & $\begin{array}{l}-0.030 \\
(-0.278 \text { to } 0.218)\end{array}$ & 0.813 & $\begin{array}{l}0.129 \\
(-0.149 \text { to } 0.407)\end{array}$ & 0.366 & $\begin{array}{l}-3.26 \\
(-6.79 \text { to } 0.28)\end{array}$ & 0.0731 & $\begin{array}{l}-0.484 \\
(-1.23 \text { to } 0.27)\end{array}$ & 0.217 \\
\hline Duration of smoking for ex-smokers (years) & $\begin{array}{l}0.00336 \\
(-0.0196 \text { to } 0.0263)\end{array}$ & 0.776 & $\begin{array}{l}-0.00728 \\
(-0.0330 \text { to } 0.0184)\end{array}$ & 0.581 & $\begin{array}{l}0.173 \\
(-0.153 \text { to } 0.500)\end{array}$ & 0.302 & $\begin{array}{l}0.0100 \\
(-0.0762 \text { to } 0.0962)\end{array}$ & 0.824 \\
\hline Current smokers & $\begin{array}{l}-0.0631 \\
(-0.165 \text { to } 0.039)\end{array}$ & 0.230 & $\begin{array}{l}0.0190 \\
(-0.095 \text { to } 0.133)\end{array}$ & 0.747 & $\begin{array}{l}-1.56 \\
(-3.02 \text { to }-0.11)\end{array}$ & 0.0366 & $\begin{array}{l}-0.0392 \\
(-0.431 \text { to } 0.353)\end{array}$ & 0.848 \\
\hline Pack-years for current smokers & $\begin{array}{l}0.00113 \\
(-0.00412 \text { to } 0.00636)\end{array}$ & 0.676 & $\begin{array}{l}0.00305 \\
(-0.00282 \text { to } 0.00891)\end{array}$ & 0.313 & $\begin{array}{l}-0.0694 \\
(-0.144 \text { to } 0.005)\end{array}$ & 0.0705 & $\begin{array}{l}-0.0370 \\
(-0.0618 \text { to }-0.0122)\end{array}$ & 0.0046 \\
\hline Operation & $\begin{array}{l}-0.0125 \\
(-0.153 \text { to } 0.128)\end{array}$ & 0.863 & $\begin{array}{l}0.0731 \\
(-0.084 \text { to } 0.230)\end{array}$ & 0.365 & $\begin{array}{l}-1.46 \\
(-3.45 \text { to } 0.541)\end{array}$ & 0.156 & $\begin{array}{l}-0.479 \\
(-1.06 \text { to } 0.101)\end{array}$ & 0.115 \\
\hline Maintenance & $\begin{array}{l}0.0154 \\
(-0.152 \text { to } 0.183)\end{array}$ & 0.858 & $\begin{array}{l}0.0523 \\
(-0.135 \text { to } 0.240)\end{array}$ & 0.587 & $\begin{array}{l}-0.669 \\
(-3.05 \text { to } 1.71)\end{array}$ & 0.585 & $\begin{array}{l}-0.523 \\
(-1.17 \text { to } 0.125)\end{array}$ & 0.123 \\
\hline Electricity & $\begin{array}{l}-0.0145 \\
(-0.240 \text { to } 0.211)\end{array}$ & 0.900 & $\begin{array}{l}-0.0252 \\
(-0.278 \text { to } 0.228)\end{array}$ & 0.846 & $\begin{array}{l}-0.298 \\
(-3.51 \text { to } 2.91)\end{array}$ & 0.857 & $\begin{array}{l}0.0456 \\
(-0.99 \text { to } 1.08)\end{array}$ & 0.933 \\
\hline $\begin{array}{l}\text { R square } \\
\text { No. of observations } \dagger\end{array}$ & $\begin{array}{l}0.0035 \\
613\end{array}$ & & $\begin{array}{l}0.0054 \\
613\end{array}$ & & $\begin{array}{l}0.0231 \\
613\end{array}$ & & $\begin{array}{l}0.0647 \\
202\end{array}$ & \\
\hline
\end{tabular}


Table 3 Characteristics of subjects with age $\geqslant 18$ years and history in coke ovens $\geqslant 1$ year at the dates of last sets of lung function tests

\begin{tabular}{|c|c|c|c|c|c|}
\hline & \multicolumn{4}{|l|}{ Group } & \multirow[b]{2}{*}{ Total } \\
\hline & Operation & Maintenance & Electricity & Other & \\
\hline Total subjects (no.) & 448 & 180 & 112 & 94 & 834 \\
\hline \multirow{2}{*}{$\begin{array}{l}\text { Subjects with } \quad 1 \text { set tests } \\
2 \text { or more sets }\end{array}$} & 85 & 77 & 53 & 41 & 256 \\
\hline & 363 & 103 & 59 & 53 & 578 \\
\hline \multirow{2}{*}{$\begin{array}{l}\text { Sets of tests, mean (SD) } \\
\text { Span between first and last tests*, mean (SD) }\end{array}$} & $5.9(3.8)$ & $3.9(3.6)$ & $4.0(3.6)$ & $2.9(2.7)$ & $4.9(3.8)$ \\
\hline & $7.8(3.2)$ & $7.2(3.3)$ & $7.6(3.1)$ & $4.8(3.4)$ & $7.4(3.3)$ \\
\hline Age (years), mean (SD) & 42.4 (12.0) & $40.8(14.6)$ & $40.1(14.1)$ & $41.8(13.3)$ & $41.7(13.0)$ \\
\hline Min-max (years) & $18.5-65.0$ & $19.9-65.5$ & $19.7-64.4$ & $18.8-64.5$ & $18.5-65.5$ \\
\hline Height $(\mathrm{cm})$, mean (SD) & $170.8(7.3)$ & $172.3(6.9)$ & $174.0(8.1)$ & $174.2(7.9)$ & $171.9(7.5)$ \\
\hline Min-max $(\mathrm{cm})$ & $140-191$ & $153-194$ & $154-196$ & $158-194$ & $140-196$ \\
\hline Non-smokers, no. (\%)† & $81(18)$ & 34 (19) & $22(20)$ & $12(13)$ & 149 (18) \\
\hline Ex-smokers, no. $(\%) \dagger$ & $105(23)$ & $36(20)$ & $25(22)$ & $17(18)$ & $183(22)$ \\
\hline Smoking duration (years), mean (SD) & $15.6(10.7)$ & $18.9(13.3)$ & $17.2(10.9)$ & $13.9(11.1)$ & $16.3(11.3)$ \\
\hline Current smokers, no. $(\%) \dagger$ & $262(59)$ & $110(61)$ & $65(58)$ & 65 (69) & $502(60)$ \\
\hline Pack-years, mean (SD) & $13.7(16.3)$ & $13.1(20.2)$ & $14.0(21.1)$ & $13.0(23.1)$ & $13.5(18.7)$ \\
\hline \multirow{2}{*}{$\begin{array}{l}\text { Work duration in "operation" (years), mean (SD) } \\
\text { Work duration other than in "operation" (years), mean (SD) }\end{array}$} & $11.6(7.9)$ & $0.6(1.8)$ & $0.2(1.0)$ & $0.5(1.3)$ & $6.4(8.1)$ \\
\hline & $0.5(1.8)$ & $11.1(9.3)$ & $11.1(8.5)$ & $10.7(8.6)$ & $5.4(8.1)$ \\
\hline \multirow{2}{*}{$\begin{array}{l}\text { Pure history } \ddagger \text {, no. }(\%) \\
\text { Mixed history§, no. (\%) }\end{array}$} & $365(81)$ & $101(56)$ & 77 (69) & $59(63)$ & $602(72)$ \\
\hline & 83 (19) & $79(44)$ & $35(31)$ & $35(37)$ & $232(28)$ \\
\hline \multicolumn{6}{|c|}{$\begin{array}{l}\text { *Only subjects with two or more sets of tests are included. } \\
\text { †Proportions of non-smokers, ex-smokers, and current smokers in each group. } \\
\text { †Pure history means subjects had only one type of work position during the lung function surveillance period. } \\
\text { §Mixed history means subjects had more than one type of work position during the lung function surveillance period. }\end{array}$} \\
\hline
\end{tabular}

Exposure data from the payment system have their limitations in reflecting the real exposure levels for each subject, but such data are generally regarded as reliable in retrospective studies. ${ }^{11} 29$

According to our exposure classification method, around $28 \%$ of subjects had mixed work histories (table 3 ). This limits our capability to identify the exposure effect associated with work locations. However, we used work duration in a particular position as our primary indicator. Also, for workers classified in "operation", the average time spent working in "operation" was more than 20 times longer than that spent elsewhere, and vice verse. Thus, any misclassification of work location has minimal effect.

Selection bias associated with the recruitment process was not observed in the four exposure groups. Regression results show that lung function of new starters did not significantly differ among exposure categories. Clearly, this is only a partial analyses of selection bias, since it is based on only around $45 \%$ of all subjects (613 of 1377 subjects).

There are two reasons to pool the last sets of lung function tests for all subjects and treat them as cross sectional data. Firstly, subjects entered and left the system at different times during the 12 year surveillance period. Any narrow time interval, for example one year, would only include a small portion of all the subjects. Secondly, there were 797 subjects (around $58 \%$ ) with only one set of lung function tests. They could not be included in a longitudinal analysis, but including them in the cross sectional study improves the power of analysis and avoids selection bias. Findings related to changes over time are extrapolations from the cross sectional analyses, and should not be expected to be equivalent to results from a true longitudinal analysis.

It is not surprising that the $\mathrm{R}^{2}$ values for all fitted regressions (tables 2 and 4 ) are relatively small because the effects of age and height have been excluded. The effects of sex, age, and height on lung function are far more important than other factors. Sex, age, and height have been reported to account for approximately $30 \%, 8 \%$, and $20 \%$, respectively, of the variation of lung function in adults. ${ }^{15}$ The most appropriate reference data were used (Gore et al). ${ }^{24}$ However, it has to be noted that the study population in question is reported to be of predominantly Southern European origin. Correction for ethnicity could not be made, as this was not recorded in the surveillance system.

Overall, the results showed that the duration of working in "operation" and/or working in "operation" were associated with lower lung function. These effects were observed for $\mathrm{FEV}_{1}$ and FVC, but not for $\mathrm{FEV}_{1} / \mathrm{FVC}$ and $\mathrm{FEF}_{25-75 \%}$. Similar findings have been reported in other studies on the lung function of coke oven workers. ${ }^{1012}{ }^{13}$ In the study by Walker et al on 881 male coke oven workers, ${ }^{10} \mathrm{FEV}_{1}$ was the only measured lung function index. Working at coke ovens was reported to be associated with a drop in mean $\mathrm{FEV}_{1}$ of around $50 \mathrm{ml} /$ year $(\mathrm{p}<0.01)$. Corhay et al compared the lung function of 137 male coke oven workers with those of 150 male blast furnace workers. ${ }^{12}$ The average FEV , percentage of the predicted values (96.8 (SD 13.5)) was significantly lower than that of blast furnace workers ( $100($ SD 12.7) $)(p<0.05)$. Madison et al investigated 3799 male coke oven workers. ${ }^{13}$ Among them were 2893 white workers and 906 black workers. After adjusting $\mathrm{FEV}_{1}$ for age, height, and years at the coke ovens, they found that job location at the coke ovens had a significant effect on FEV , for white workers $(p<0.0001)$. The difference between the most exposed group and the least exposed group was around $470 \mathrm{ml}$ for smokers and around $300 \mathrm{ml}$ for non-smokers. However, for black workers, no job location effect on FEV , was found. In our study, FEV, was also significantly affected by each year of working in "operation", although the magnitude was less than effects found by Walker et al and Madison et al. Such differences in magnitude might be explained by different concentrations of coke oven emissions in different working environments. ${ }^{22}$

An effect of exposure to coke oven emissions on FVC was also observed in our study, but FVC was not reported in the studies by Corhay and colleagues and Madison and colleagues. ${ }^{12}{ }^{13}$ Chau et al investigated 354 retired male coke oven workers. ${ }^{11}$ They found no effect of exposure to coke oven emissions on FVC, nor on other lung function indices $\left(\mathrm{FEV}_{1}\right.$, $\mathrm{FEV}_{1} / \mathrm{FVC}$, and $\mathrm{FEF}_{25-75 \%}$ ). They attributed the lack of association to bias of participants, healthy worker effect, and the exclusion of deceased subjects. 


\begin{tabular}{|c|c|c|c|c|c|c|c|c|}
\hline & \multicolumn{2}{|l|}{$\mathrm{FEV}_{1}(\mathrm{l})$} & \multicolumn{2}{|l|}{$\mathrm{FVC}(\mathrm{I})$} & \multicolumn{2}{|l|}{$\mathrm{FEV}_{1} / \mathrm{FVC}(\%)$} & \multicolumn{2}{|l|}{$\mathrm{FEF}_{25-75 \%}(\mathrm{I} / \mathrm{s})$} \\
\hline & Coefficient & $\mathrm{p}$ value & Coefficient & $\mathrm{p}$ value & Coefficient & $\mathrm{p}$ value & Coefficient & $\mathrm{p}$ value \\
\hline Intercept & $\begin{array}{l}3.70 \\
(3.54 \text { to } 3.85)^{*}\end{array}$ & 0.0001 & $\begin{array}{l}4.54 \\
(4.37 \text { to } 4.70)\end{array}$ & 0.0001 & $\begin{array}{l}80.9 \\
(78.6 \text { to } 83.1)\end{array}$ & 0.0001 & $\begin{array}{l}3.99 \\
(3.46 \text { to } 4.52)\end{array}$ & 0.0001 \\
\hline Ex-smokers & $\begin{array}{l}0.166 \\
(0 \text { to } 0.331)\end{array}$ & 0.0517 & $\begin{array}{l}0.139 \\
(-0.0376 \text { to } 0.315)\end{array}$ & 0.126 & $\begin{array}{l}2.62 \\
(0.225 \text { to } 5.02)\end{array}$ & 0.0334 & $\begin{array}{l}0.272 \\
(-0.166 \text { to } 0.710)\end{array}$ & 0.230 \\
\hline Duration of smoking for ex-smokers (years) & $\begin{array}{l}-0.0128 \\
(-0.0200 \text { to }-0.0055)\end{array}$ & 0.0006 & $\begin{array}{l}-0.00805 \\
(-0.0157 \text { to }-0.00035)\end{array}$ & 0.0420 & $\begin{array}{l}-0.253 \\
(-0.358 \text { to }-0.148)\end{array}$ & 0.0001 & $\begin{array}{l}-0.0358 \\
(-0.0548 \text { to }-0.0167)\end{array}$ & 0.0003 \\
\hline Current smokers & $\begin{array}{l}-0.116 \\
(-0.223 \text { to }-0.010)\end{array}$ & 0.0341 & $\begin{array}{l}-0.0390 \\
(-0.152 \text { to } 0.074)\end{array}$ & 0.503 & $\begin{array}{l}-1.85 \\
(-3.40 \text { to }-0.31)\end{array}$ & 0.0195 & $\begin{array}{l}-0.304 \\
(-0.643 \text { to } 0.035)\end{array}$ & 0.0822 \\
\hline Pack-years for current smokers & $\begin{array}{l}-0.000181 \\
(-0.00285 \text { to } 0.00249)\end{array}$ & 0.895 & $\begin{array}{l}-0.000550 \\
(-0.00339 \text { to } 0.00229)\end{array}$ & 0.706 & $\begin{array}{l}-0.0407 \\
(-0.0793 \text { to }-0.00208)\end{array}$ & 0.0404 & $\begin{array}{l}-0.0198 \\
(-0.0310 \text { to }-0.0087)\end{array}$ & 0.0006 \\
\hline Operation & $\begin{array}{l}0.0120 \\
(-0.143 \text { to } 0.167)\end{array}$ & 0.880 & $\begin{array}{l}-0.0707 \\
(-0.235 \text { to } 0.094)\end{array}$ & 0.403 & $\begin{array}{l}1.74 \\
(-0.49 \text { to } 3.98)\end{array}$ & 0.129 & $\begin{array}{l}0.0327 \\
(-0.504 \text { to } 0.570)\end{array}$ & 0.906 \\
\hline Maintenance & $\begin{array}{l}-0.0164 \\
(-0.154 \text { to } 0.121)\end{array}$ & 0.816 & $\begin{array}{l}-0.0151 \\
(-0.161 \text { to } 0.131)\end{array}$ & 0.841 & $\begin{array}{l}0.207 \\
(-1.78 \text { to } 2.19)\end{array}$ & 0.839 & $\begin{array}{l}0.0869 \\
(-0.399 \text { to } 0.573)\end{array}$ & 0.729 \\
\hline Electricity & $\begin{array}{l}-0.0359 \\
(-0.187 \text { to } 0.115)\end{array}$ & 0.644 & $\begin{array}{l}-0.0495 \\
(-0.210 \text { to } 0.111)\end{array}$ & 0.548 & $\begin{array}{l}-0.226 \\
(-2.41 \text { to } 1.96)\end{array}$ & 0.840 & $\begin{array}{l}-0.0429 \\
(-0.575 \text { to } 0.489)\end{array}$ & 0.876 \\
\hline Work duration in "operation" (years) & $\begin{array}{l}-0.00945 \\
(-0.0162 \text { to }-0.0027)\end{array}$ & 0.0062 & $\begin{array}{l}-0.0116 \\
(-0.0187 \text { to }-0.0044)\end{array}$ & 0.0016 & $\begin{array}{l}-0.0856 \\
(-0.183 \text { to } 0.012)\end{array}$ & 0.0866 & $\begin{array}{l}-0.00239 \\
(-0.0234 \text { to } 0.0186)\end{array}$ & 0.825 \\
\hline Work duration other than in "operation" (years) & $\begin{array}{l}-0.00206 \\
(-0.00853 \text { to } 0.00441)\end{array}$ & 0.536 & $\begin{array}{l}-0.00748 \\
(-0.0144 \text { to }-0.0006)\end{array}$ & 0.0344 & $\begin{array}{l}0.0695 \\
(-0.0241 \text { to } 0.163)\end{array}$ & 0.149 & $\begin{array}{l}0.00705 \\
(-0.0133 \text { to } 0.0274)\end{array}$ & 0.502 \\
\hline $\begin{array}{l}\text { R square } \\
\text { No. of observations } \dagger\end{array}$ & $\begin{array}{l}0.0372 \\
834\end{array}$ & & $\begin{array}{l}0.0358 \\
833\end{array}$ & & $\begin{array}{l}0.0508 \\
833\end{array}$ & & $\begin{array}{l}0.0811 \\
500\end{array}$ & \\
\hline
\end{tabular}


In this study, no evidence was found that $\mathrm{FEV}_{1} / \mathrm{FVC}$ and $\mathrm{FEF}_{25-75 \%}$ were significantly affected by exposure to coke oven emissions. Corhay et al did not find that $\mathrm{FEV}_{\mathrm{l}} / \mathrm{VC}$ was significantly affected in coke oven workers, though they reported the average $\mathrm{FEF}_{25-75 \%}$ percentage of the predicted value in coke oven workers (82.4 (SD 27.0)) was significantly lower than that of blast furnace workers (96.7 (SD 30.4)). ${ }^{12}$ Madison et al found no effect of work location on $\mathrm{FEV}, \mathrm{FVC}$ for black subjects, and a small effect for white subjects. ${ }^{13}$ Chau et al found that $\mathrm{FEV}_{1} / \mathrm{FVC}$ and $\mathrm{FEF}_{25-75 \%}$ of subjects in the non-exposed group were lower than those of subjects in the exposed groups. ${ }^{11}$ It has been reported that $\mathrm{FEV}_{\mathrm{l}} / \mathrm{FVC}$ may be unchanged or even become higher when FVC is reduced more than $\mathrm{FEV}_{1}$ in restrictive lung defects. ${ }^{15}{ }^{30}{ }^{31}$ It has also been claimed that $\mathrm{FEF}_{25-75 \%}$ might not be affected even if $\mathrm{FEV}_{1}$ and FVC are affected. ${ }^{15} 32$

An effect of past smoking on lung function was also observed in this study. Our analyses suggested that exsmokers had worse $\mathrm{FEV}_{\mathrm{l}} / \mathrm{FVC}$ than non-smokers if they smoked for more than 10 years (table 4 ). However, ex-smokers with shorter duration of smoking than 10 years had better $\mathrm{FEV}_{1} / \mathrm{FVC}$. Such an observation is not unique to this study. FVC for ex-smokers can become more like that of nonsmokers after giving up smoking. ${ }^{33}$ The lung function decrement for ex-smokers might be reversible before chronic bronchitis has developed. ${ }^{34}$

For current smoking, we found effects on $\mathrm{FEV}_{1} / \mathrm{FVC}$ and $\mathrm{FEV}_{1}$ but not on FVC. An effect of smoking on $\mathrm{FEV}_{1} / \mathrm{FVC}$ is often found together with a $\mathrm{FEV}_{1}$ effect in the absence of an effect on FVC. ${ }^{31}$ Other authors have found that FEV of smokers was more affected than FVC. ${ }^{15}{ }^{35}$ There have been similar findings in other occupational investigations. ${ }^{36-38}$

From our regressions (table 4) and those of Gore and colleagues, ${ }^{24}$ we can estimate lung function loss for a non-smoking worker (height $=175 \mathrm{~cm}$ ) working continuously in "operation" during a working life of 35 years, from age 25 to age 60 . The FEV loss caused by working in "operation" is around $320 \mathrm{ml}$ (or $9 \mathrm{ml} / \mathrm{year}$ ) and that caused by aging is around $970 \mathrm{ml}$ (or $28 \mathrm{ml} / \mathrm{year}$ ). The FVC loss caused by working in "operation" is around $480 \mathrm{ml}$ (or $14 \mathrm{ml} /$ year), and that caused by aging is around $820 \mathrm{ml}$ (or $22 \mathrm{ml} /$ year). Thus, the estimated $\mathrm{FEV}_{1}$ loss caused by working in "operation" accounts for around 25\% of total FEV loss in the work life of a non-smoker. The percentage for FVC is around $37 \%$. Smoking 35 pack-years will cause additional reduction in $\mathrm{FEV}_{1}$ of around $120 \mathrm{ml}$ (or $3.4 \mathrm{ml} / \mathrm{year}$ ) and in FVC of around $58 \mathrm{ml}$ (or $2 \mathrm{ml} /$ year). Since aging effects for $\mathrm{FEV}_{1}$ and for FVC reported by Gore et al are broadly similar to those in other reference regressions, ${ }^{27} 28$ the above indication of percentage of loss attributable to the work place should be generally applicable.

The FEV and FVC losses each year in the present study are similar to the findings from 13903 steel workers reported by Lowe and colleagues. ${ }^{39}$ Workers from steelworks departments such as coke ovens, blast furnaces, steelmaking, hot mill, and cold mill were included. It was reported that the FEV loss was about $40 \mathrm{ml} /$ year and FVC loss was about $35 \mathrm{ml} /$ year.

The pattern of lung function effects from exposure to coke oven emissions seems different from those caused by smoking but similar to those caused by coal dust. Smoking usually causes a lung function pattern typical of obstructive lung disease, which is associated with decreased $\mathrm{FEV}_{1} / \mathrm{FVC}^{15}$ Both $\mathrm{FEV}_{1}$ and FVC have been reported to be lowered by similar amounts by coal dust, ${ }^{29}$ which might be interpreted as damage at the alveolar level. ${ }^{31}$ For active non-smoking coal miners, the FEV, loss was reported by Bates et al to be around $46 \mathrm{ml} /$ year and that for FVC was around $40 \mathrm{ml} / \mathrm{year} .^{30}$ Love et al reported that the FEV, loss each year for non-smoking coal miners was about $39 \mathrm{ml} /$ year. $^{40}$ Our results are consistent with these results.

In conclusion, work time in "operation" was observed to have a negative effect on $\mathrm{FEV}_{1}$ and FVC. Such findings in a cross sectional study suggest the value of a longitudinal analysis of the relevant data from the database from which these cross sectional data were extracted. This will be reported separately.

\section{ACKNOWLEDGEMENTS}

The authors are indebted to Mrs Helen Calvert and her colleagues for their provision of data and help in data collection, and to the University of Wollongong for financial support.

\section{Authors' affiliations}

J Wu, I A Kreis, Graduate School of Public Health, University of Wollongong, Australia

D Griffiths, School of Mathematics \& Applied Statistics, University of Wollongong, Australia

C Darling, BHP Flat Products Division Port Kembla, Australia

\section{REFERENCES}

1 Smith WM. Evaluation of coke oven emissions. J Occup Med 1971:13:69-74.

2 Dancy TE. Control of coke oven emissions. J Occup Med $1971 ; 13: 75-82$.

3 Wilson PJ, Wells JH. Coal, coke and coal chemicals. London: McGaw-Hill Book Co. Inc., 1950:1-5.

4 Davies GM, Hodkinson A, DiVetta P. Measurement and analysis of occupational exposures to coke oven emissions. Ann Occup Hyg 1986;30:51-62.

5 Lloyd JW. Long-term mortality study of steelworkers. V. Respiratory cancer in coke plant workers. J Occup Med 1971:13:53-68.

6 Redmond CK, Ciocco A, Lloyd JW, et al. Long-term mortality study of steelworkers. VI. Mortality from malignant neoplasms among coke oven workers. J Occup Med 1972;14:621-9

7 Redmond CK, Strobino BR, Cypess RH. Cancer experience among coke by-product worker. Ann N Y Acad Sci 1976;271:102-15.

8 Mancuso TF. Lung cancer among black migrants. Interaction of host and occupational environment factors. J Occup Med 1977;19:531-2.

9 Swaen GMH, Slangen JJM, Volovics A, et al. Mortality of coke plant workers in the Netherlands. Br J Ind Med 1991:48:130-5.

10 Walker DD, Archibald RM, Attfield MD. Bronchitis in men employed in the coke industry. Br J Ind Med 1971;28:358-63.

11 Chau N, Bertrand JP, Guenzi M, et al. Lung function in retired coke oven plant workers. Br J Ind Med 1992;49:316-25.

12 Corhay JL, Bury T, Louis R, et al. Bronchial responsiveness in active steelworkers. Eur Respir J 1998;11:272-7.

13 Madison R, Afifi AA, Mittman C. Respiratory impairment in coke oven workers: relationship to work exposure and bronchial inflammation detected by sputum cytology. J Chron Dis 1984;37:167-76.

14 USA Department of Labour, Occupational Safety and Health Administration. Final occupational safety and health standard for exposure to coke oven emissions. Federal Register 1976;41:46742-93.

15 American Thoracic Society. Lung function testing: selection of reference values and interpretative strategies. Am Rev Respir Dis 1991;144:1202-18.

16 Hoek G, Brunekreef B. Time trends in repeated spirometry in children. Eur Respir J 1992;5:553-9.

17 Burton P, Gurrin L, Sly P. Extending the simple linear regression model to account for correlated responses: an introduction to generalized estimating equations and multi-level mixed modelling. Stat Med 1998;17:1261-91.

18 Cole TJ. Height standardization of ventilatory function. Proc R Soc Med 1977;70: 165-6.

19 Cole TJ. Linear and proportional regression models in the prediction of ventilatory function. J R Statist Soc A 1975;138:297-325.

20 Ericsson P, Irnell L. Spirometric studies of ventilatory capacity in elderly people. Acta Med Scand 1969;185:179-84.

21 Schoenberg JB, Beck GJ, Bouhuys A. Growth and decay of pulmonary function in healthy blacks and whites. Respir Physiol 1978:33:367-93.

22 Vollmer WM, Johnson LR, McCamant LE, et al. Longitudinal versus cross-sectional estimation of lung function decline-further insights. Stat Med 1988;7:685-96.

23 Vollmer WM, Johnson LR, McCamant LE, et al. Methodological issues in the analysis of lung function data. J Chron Dis 1987;40:1013-23.

24 Gore CJ, Crockett AJ, Pederson DG, et al. Spirometric standards for healthy adult lifetime nonsmokers in Australia. Eur Respir J 1995;8:773-82

25 Morris JF, Koski A, Johnosn LC. Spirometric standards for healthy nonsmoking adults. Am Rev Respir Dis 1971;103:57-67.

26 Gibson J, Gallagher H, Johansen A, et al. Lung function in an Australian population. I. Spirometric standards for nonsmoking adults. Med J Aust 1979;1:292-5

27 Crapo RO, Morris AH, Gardner RM. Reference spirometric values using techniques and equipment that meet ATS recommendations. Am Rev Respir Dis 1981;123:659-64. 
28 Quanjer PH, Tammeling GJ, Cotes JE, et al. Lung volume and forced ventilatory flows. Report Working Party Standardization of Lung Function Tests, European Community for Steel and Coal. Official Statement of the European Respiratory Society. Eur Respir J 1993;6(suppl 16):5-40.

29 Soutar CA, Hurley JF. Relation between dust exposure and lung function in miners and ex-miners. Br J Ind Med 1986;43:307-20.

30 Bates DV, Pham QT, Chau N, et al. A longitudinal study of pulmonary function in coal miners in Lorraine, France. Am J Ind Med 1985;8:21-32.

31 West JB. Pulmonary pathophysiology-the essentials, 4th edn. Baltimore: Williams \& Wilkins, 1992:3-147.

32 Hankinson JL. Pulmonary function testing in the screening of workers: guidelines for instrumentation, performance, and interpretation. J Occup Med 1986;28:1081-92.

33 Ashley F, Kannel WB, Sorlie PD, et al. Pulmonary function: relation to aging, cigarette habit, and mortality-the Framingham Study. Ann Intern Med 1975; 82:739-45.

34 Huhti E. Ventilatory function in healthy non-smokers and smokers. Scand J Respir Dis 1967;48:149-55.
35 Bande J, Clement J, Van De Woestijne KP. The influence of smoking habits and body weight on vital capacity and $\mathrm{FEV}_{1}$ in male air force personnel: a longitudinal and cross-sectional analysis. Am Rev Respir Dis 1980;122:781-90.

36 Jörgensen HS, Kolmodin-Hedman B, Stjernberg N. Follow-up study of pulmonary function and respiratory tract symptoms in workers in a Swedish iron ore mine. J Occup Med 1988;30:953-8.

37 Attfield MD, Trabant GD, Wheeler RW. Exposure to dust and diesel fumes at six potash mines. Inhaled particles VI. Am J Occup Hyg 1982;26:816-29.

38 Gamble J, Jones W, Hudak J. An epidemiological study of salt miners in diesel and non-diesel mines. Am J Ind Med 1983;4:435-8.

39 Lowe CR, Pelmear PL, Campbell H, et al. Bronchitis in two integrated steel works. I. Ventilatory capacity, age, and physique of non-bronchitic men. Br J Prev Soc Med 1968;22:1-11.

40 Love RG, Miller BG. Longitudinal study of lung function in coal-miners. Thorax 1982;37:193-7.

\section{$\mathrm{ECHO}$}

\section{Bar and restaurant staff are regularly overexposed}

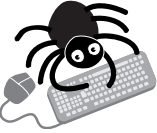

Please visit the Occupational and

Environmental website [www.occenvmed. com] for link to this full article. taff in bars and restaurants where the policy permits or limits smoking to certain areas absorb damagingly high amounts of nicotine, finds a study in New Zealand, the first of its kind there to determine objectively whether exposure to environmental tobacco smoke (ETS) varies with smoking policy.

A significantly greater proportion of staff had a higher cotinine concentration in their saliva after a work shift when customer smoking was unrestricted (83\%) or limited $(40 \%)$ than staff in non-smoking establishments (13\%).

Cotinine concentration increased according to the policy of the workplace (median concentration for government staff $0.15 \mathrm{ng} / \mathrm{g}$; for staff in workplaces with a policy of no smoking $0.1 \mathrm{ng} / \mathrm{g}$, restricted smoking $1.6 \mathrm{ng} / \mathrm{g}$, or unrestricted smoking $1.7 \mathrm{ng} / \mathrm{g}$ ). When staff in each workplace were grouped by whether their cotinine rose or not the resulting trend was significant, showing a link between fewer restrictions and increased salivary cotinine.

The study recruited staff in 29 different bars and restaurants. All were non-smokers for six months or more and were not using nicotine replacement therapy. Their workplace permitted unrestricted customer smoking (12 subjects), restricted smoking (20), or no smoking (10). To compensate for the size of the non-smoking group 50 non-smoking government workers were included as a separate category. Saliva was collected from each worker immediately before and after a work shift.

In New Zealand smoking is restricted by law in the workplace but is permitted in enclosed areas where alcohol is served. Here workers inhale high levels of ETS over long periods.

A Tobacco Control 2002;11:125-129 